Veranica Cheristien, Eko Harry Susanto: Pergeseran Makna Perayaan Tahun Baru Imlek bagi Etnis

Tionghoa di Jakarta

\title{
Pergeseran Makna Perayaan Tahun Baru Imlek Bagi Etnis Tionghoa di Jakarta
}

\author{
Veranica Cheristien, Eko Harry Susanto \\ veranicamerry@gmail.com,ekos@fikom.untar.ac.id \\ Fakultas Ilmu Komunikasi Universitas Tarumanagara
}

\begin{abstract}
This research is titled Shifting the Meaning of Chinese New Year Celebration for Chinese Ethnics in Jakarta. The aim of the study was to determine the shift in meaning of the present Chinese New Year Celebration for Chinese Ethnics. This study identified the problem of shifting the meaning of Chinese New Year Celebration, Preparations for the Lunar New Year Celebration and the Cause of Tradition Shift in Chinese New Year. This study uses phenomenological research methods, namely methods that analyze through views of events that are experienced directly. The study will use in-depth observations and interviews with Chinese Culture Experts and Chinese Ethnics to support the results of the author's research. The research data was obtained from observation, interviews, literature studies and online data. The theories used in this study are Intercultural Communication, Cultural Characteristics, Traditions in Culture and Meanings. The conclusion of this study is the meaning of the Chinese New Year Celebration is now different from the actual meaning for some Chinese Ethnics. Chinese New Year Celebration is the most important celebration for Chinese Ethnics, Chinese New Year Celebration also contains sacred traditional values for some Chinese Ethnics.
\end{abstract}

Keyword : Chinese New Year Celebration, Difference in Imlek, Chinese Ethnicity

\begin{abstract}
Abstrak
Penelitian ini mengankat tentang pergeseran makna Perayaan Tahun Baru Imlek bagi etnis Tionghoa di Jakarta. Tujuan penelitian adalah untuk mengetahui pergeseran makna Perayaan Tahun Baru Imlek sekarang bagi Etnis Tionghoa. Penelitian ini mengidentifikasi masalah pergeseran makna Perayaan Tahun Baru Imlek, Persiapan Menjelang Perayaan Tahun Baru Imlek serta Penyebab Pergeseran Tradisi Perayaan Tahun Baru Imlek. Penelitian ini menggunakan metode penelitian fenomenologi yaitu metode yang menganalisis melalui pandangan terhadap kejadian yang dialami secara langsung. Penelitian menggunakan observasi dan wawancara yang mendalam dengan ahli budaya Tionghoa dan etnis Tionghoa untuk mendukung hasil penelitian penulis. Data penelitian diperoleh dari observasi, wawancara, studi pustaka dan data online. Penelitian ini menggunakan konsep komunikasi antar budaya, karakteristik budaya, traadisi dalam budaya dan makna. Kesimpulan dari penelitian ini adalah makna Perayaan Tahun Baru Imlek sekarang sudah berbeda dengan makna sebenarnya bagi sebagian etnis Tionghoa. Perayaan Tahun Baru Imlek merupakan perayaan terpenting bagi Etnis Tionghoa, Perayaan Tahun Baru Imlek juga mengandung nilai tradisi yang sakral bagi sebagian Etnis Tionghoa.
\end{abstract}

Kata kunci : Perayaan Tahun Baru Imlek, Perbedaan makna Imlek, Etnis Tionghoa 


\section{Pendahuluan}

Sistem komunikasi verbal dan nonverbal membedakan suatu kelompok dari kelompok lainnya (Mulyana dan Rakhmat, 2010:58). Komunikasi dan kebudayaan merupakan dua aspek yang tidak dapat saling dipisahkan dari kehidupan bermasyarakat (Liliweri, 2003:12). Kebudayaan merupakan cara hidup, pikiran, akal sehat, dan adat istiadat yang dimiliki seseorang atau kelompok orang yang merupakan sebuah warisan dari generasi ke generasi. Budaya dapat berupa bahasa, prilaku, adat istiadat, karya seni ataupun pikiran. Setiap daerah atau negara memiliki budaya berbeda-beda dan beragam yang patut untuk dipatuhi oleh setiap pendatang baru. Kebudayaan juga mengandung nilai dan norma yang berlaku bagi setiap daerahnya.

Adat istiadat dan kepercayaan Tionghoa direvitalisasi oleh Gus Dur (Abdurahman Wahid) yang terpilih sebagai Presiden pada tahun 1999 seiring dengan lengsernya Presiden Soeharto. Presiden Gus Dur pada masanya juga mencabut Inpres No. 14 Tahun 1967 tentang pelarangan terhadap berbagai ekspresi budaya Etnis Tionghoa di Indonesia. Hal ini mendorong masyarakat Etnis Tionghoa Indonesia secara langsung atau tidak langsung berpartisipasi dalam segala kegiatan tradisi kebudayaan di Indonesia baik di daerah maupun di kota, perseorangan maupun berkelompok, yang merupakan perubahan signifikan bagi masyarakat Etnis Tionghoa Indonesia.

Tahun Baru Cina atau yang lebih sering dikenal Imlek merupakan perayaan penting bagi orang Tionghoa, Perayaan Tahun Baru Imlek dimulai pada hari pertama bulan pertama di penanggalan Tionghoa dan berakhir dengan Cap Go Meh pada tanggal ke-15 pada saat bulan purnama. Di Tiongkok, adat dan tradisi wilayah yang berkaitan dengan Perayaan Tahun Baru Imlek sangat beragam. Dimulai dari dengan adanya berbagai pantangan yang dilakukan dari persiapan malam Tahun Baru Imlek hingga hari raya Imlek (Hasanah, 2014). Dalam menyambut datangnya Tahun Baru Imlek warga Tionghoa memiliki kebiasaan untuk membersihkan rumah beberapa hari sebelum Perayaan Tahun baru Imlek. Diyakini bahwa membersihkan rumah memiliki makna yaitu untuk membuang ketidakberuntungan dan nasib buruk yang ada di rumah tersebut. Selain membersihkan rumah mengganti perabotan rumah yang sudah usang, menghias rumah dengan pernak-pernik bernuansa merah dan emas hingga mengecat dinding rumah hingga menjadi seperti baru lagi sudah menjadi kebiasaan warga Tionghoa dalam mempersiapkan Tahun Baru Cina.

\section{Metode Penelitian}

Penulis memilih menggunakaan metode penelitian fenomenologi dengan pendekatan penlitian kualitatif yang bersifat deskriptif. Penulis memilih menggunakan penelitian kualitatif, memungkinkan penulis untuk mendapatkan informasi dan gambaran secara mendalam mengenai pandangan Etnis Tionghoa pada Perayaan Tahun Baru Imlek di Jakarta. Hal ini dapat memudahkan penulis dalam menemukan masalah dan menganalisa yang terjadi di masyarakat dan dapat dituangkan ke dalam penelitian ini.

Fenomenologi berarti melihat dari sudut pandang orang yang secara langsung mengalaminya. Tidak hanya mengklasifikasikan tindakan sadar yang dilakukan namun fenomenologi juga meliputi prediksi terhadap tindakan dimasa yang akan datang, dapat 
Veranica Cheristien, Eko Harry Susanto: Pergeseran Makna Perayaan Tahun Baru Imlek bagi Etnis Tionghoa di Jakarta

dilihat melalui aspek-aspek yang terkait kejadian yang terkait. Bagaimana cara seseorang memaknai objek dalam pengalamannya adalah seluruh sumber yang terkait (Kuswarno, 2009:10). Fenomenologi merupakan studi tentang makna. Fenomelogi memandang prilaku manusia, segala hal yang manusia katakana dan lakukan merupakan produk dari cara manusia melakukan tafsir terhadap dunia orang yang bersangkutan (Sutopo, 2006:27).

\section{Hasil dan Diskusi}

Perayaan Tahun Baru Imlek sudah memiliki makna yang berbeda bagi sebagian Etnis Tionghoa dengan makna sebenarnya. Makna sebenarnya menurut Ahli Budaya Tionghoa Dali Santun Naga adalah Perayaan Musim Semi, namun bagi sebagian Etnis Tionghoa adalah momen untuk berkumpul bersama keluarga. Persiapan yang dilakukan Etnis Tionghoa dalam mempersiapkan Perayaan Tahun Baru yaitu membersihkan rumah, menyiapkan hidangan khusus pada hari perayaan hingga menyiapkan pakaian baru berwarna merah dengan makna kegembiraan serta potong rambut. Penyebab pergeseran pada makna Perayaan Tahun Baru Imlek adalah sudah sejak adanya Tionghoa Hwe Koan di Cina, sebelum masuk ke Indonesia. Di tambah pada masa Orde Baru yang melarang warga keturunan Etnis Tionghoa untuk berekspresi. Secara tidak langsung juga menghapus hak asasi, mengakibatkan lunturnya tradisi budaya Etnis Tionghoa di Indonesia.

Perayaan Tahun Baru Cina atau yang dikenal sebagai Imlek adalah perayaan penting untuk Etnis Tionghoa, sehingga setiap tahunnya secara rutin dijalankan dan diwariskan ke generasi selanjutnya, melalui orang tua dan diajarkan kepada anaknya. Budaya dipelajari melalui berbagai proses salah satunya proses enkulturasi dimana proses pembelajaran suatu budaya yang total.

Berdasarkan hasil penelitian penulis, dengan demikian gagasan yang terbentuk adalah bagi sebagian Etnis Tionghoa di Indonesia sudah keliru dalam memaknai Perayaan Tahun Baru Imlek. Makna yang ada sudah berbeda dengan makna sebenarnya, dikarenakan seiring berkembangnya zaman, serta keluarga dan lingkungan sekitar. Sesuai dengan pernyataan dari Liliweri yang mengatakan demikian, komunikasi sebagai aktifitas simbolis, karena aktifitas berkomunikasi menggunakan simbol-simbol yang bermakna dan dapat diubah kedalam verbal (kata-kata) yang ditulis dan diucapkan atau dengan simbol bukan non verbal (bukan kata kata) untuk diperagakan. Aktifitas manusia dan bentuk tindakan atau tampilan dari sebuah objek sudah dapat mewakili suatu makna (Liliweri, 2003:5).

Menjelang Perayaan Tahun Baru Imlek sudah menjadi hal yang umum bagi sebagian besar Etnis Tionghoa untuk mempersiapkan diri. Terdapat beberapa hal yang perlu diperhatikan menjelang hari Perayaan Tahun Baru Imlek seperti membersihkan rumah, menyiapkan pakaian baru berwarna merah hingga potong rambut. Dengan demikian terbentuk gagasan bahwa tradisi yang diajarkan keluarga secara turun temurun menjadi tradisi keluarga Etnis Tionghoa. Seusai dengan pernyataan Mulayana dan Rakhmat. Tradisi dapat mempengaruhi manusia melalui prilaku dan prosedur yang layak berkenaan dengan makanan, pakaian, hal-hal yang harus dihindari atau diabaikan. Selain itu, tradisi juga didefinisikan sebegai tatanan mental yang memiliki pengaruh kuat atas 
sistem moral dalam menilai hal-hal yang dianggap benar atau salah, baik atau buruk, menyenangkan maupun tidak menyenangkan (Mulyana dan Rakhmat, 2006 : 69).

Namun seiring berkembangnya zaman dan adanya pergeseran makna yang terjadi, tidak banyak Etnis Tionghoa yang masih mengikuti tradisi lama dalam menyambut datangnya Perayaan Tahun Baru Imlek. Bagi sebagian orang, persiapan seperti menyiapkan pakaian baru dan membersihkan rumah sudah bukan hal yang wajib atau dipercaya dengan arti tertentu. Gagasan ini mendukung adanya makna konotatif yang terbentuk bagi sebagian Etnis Tionghoa berdasarkan pengalaman pribadi. Dengan demikian pernyataan ini didukung oleh Langer dalam Little John makna sendiri dibagi menjadi dua bagian yaitu makna denotatif yang merupakan makna yang disetujui secara bersama dan makna konotatif, gambaran atau makna pribadi oleh seseorang yang berdasarkan pada pengalaman atau lainnya (2009: 154).

Jauh sebelum tradisi budaya Etnis Tionghoa masuk ke Indonesia, pada tahun 1900 sudah mengalami beberapa perubahan yang disebabkan munculnya Tionghoa Hwe Koan. Hingga saat sebagian etnis Tionghoa yang datang ke Indonesia melalui jalur perdagangan menikah dengan masyarakat setempat dan membawa tradisi secara turun temurun. Salah satu karakeristik budaya adalah dinamis, Luckmann dalam buku berjudul Komunikasi Lintas Budaya (Samovar, 2010:47).

Cara penyebaran tradisi budaya Etnis Tionghoa seperti Perayaan Tahun Baru Imlek salah satunya melalui keluarga. Dengan demikian ajaran dari orang tua pun sangat berpengruh terhadap budaya yang diwariskan secara turun temurun. Bila budaya sudah mulai luntur maka nilai dalam tradisi mulai hilang. Sesuai dengan pernyataan berikut yaitu cara penyebaran budaya dapat berbagai bentuk (karya seni, cerita dan pepatah) dan dapat memiliki banyak penyebar yaitu media, tema, keluarga. Gereja, sekolah dan lainnya (Samovar, 2010:44).

\section{Kesimpulan}

Perayaan Tahun Baru Imlek memiliki makna yang berbeda bagi sebagian Etnis Tionghoa dengan makna sebenarnya. Makna sebenarnya menurut Ahli Budaya Tionghoa adalah Perayaan Musim Semi, namun bagi sebagian Etnis Tionghoa adalah momen untuk berkumpul bersama keluarga. Persiapan Perayaan Tahun Baru Imlek yaitu membersihkan rumah, menyiapkan hidangan khusus pada hari perayaan hingga menyiapkan pakaian baru berwarna merah dengan makna kegembiraan serta potong rambut.

Penyebab pergeseran pada makna Perayaan Tahun Baru Imlek ada sejak adanya Tionghoa Hwe Koan di Cina pada tahun 1900, sebelum masuk ke Indonesia. Di tambah pada masa Orde Baru yang melarang warga keturunan Etnis Tionghoa untuk berekspresi. Secara tidak langsung juga menghapus hak asasi, mengakibatkan lunturnya tradisi budaya Etnis Tionghoa di Indonesia. Serta perkembangan zaman dan ajaran orang tua kepada genegrasi muda. 
Veranica Cheristien, Eko Harry Susanto: Pergeseran Makna Perayaan Tahun Baru Imlek bagi Etnis Tionghoa di Jakarta

\section{Ucapan Terima Kasih}

Puji syukur penulis panjatkan ke hadirat Tuhan yang Maha Esa, karna kehendaknya penulis dapat menyelesaikan penelitian skripsi dan juga dapat menyelesaikan penyusunan laporan skripsi tepat waktu dengan judul "Pergeseran Makna Perayaan Tahun Baru Imlek Bagi Etnis Tionghoa Di Jakarta". Penelitian serta penyusunan laporan skripsi ini dilakukan guna untuk menyelesaikan tugas mata kuliah skripsi dan juga sebagai persyaratan untuk menyelesaikan kelulusan Program Studi Strata I Fakultas Ilmu Komunikasi Universitas Tarumanagara serta untuk mencapai gelar Sarjana Ilmu Komunikasipenulis juga mengucapkan terimakasih yang sedalam dalamnya kepada pembimbing, informan serta teman teman yang mendukung penulis dalam menyelesaikan proses penelitian ini hingga selesai dan terbitnya publikasi atau hasil penelitian penulis ini.

\section{Daftar Pustaka}

Arikunto, Suharsimi. (2016). Prosedur Penelitian: Suatu Pendekatan Praktik. Jakarta: Rineka Cipta.

Bagong, Suyanto. (2005). Metode Penelitian Sosial. Jakarta: Kencana Prenada.

Baru Imlek Sebuah Tinjauan Semantik". Jurnal Skripsi Thesis. Universitas Airlangga.

Bungin, Burhan. (2010). Penelitian Kualitatif. Jakarta: Kencana Prenada Media Group. Herdiansyah, Haris. (2011). Metode Penelitian Kualitatif. Jakarta: Salemba Humanika. https://id.wikipedia.org/wiki/Tionghoa-Indonesia

https://www.tionghoa.info/pantangan-di-tahun-baru-imlek-6-hal-yang-seharusnya-tidakdilakukan-pada-saat-imlek/

Instruksi Presiden No 14 tahun 1967 mengenai pelarangan terhadap berbagai ekspresi budaya Etnis Tionghoa.

Konsepsi, Pedoman dan Contoh Penelitiannya. Bandung: Widya Padjadjaran

Kuswarno, Engkus. (2009). Metode Penelitian Komunikasi: Fenomenologi,

Liliweri, Alo. (2002). Makna Budaya Dalam Komunikasi Antarbudaya. Yogyakarta: LKiS Yogyakarta.

Moleong, Lexy J. (2012). Metodologi Penelitian Kualitatif. Bandung : Remaja Rosdakarya.

Moleong, Lexy J. (2014). Metode Penelitian Kualitatif. Bandung: PT Remaja Rosdakarya.

Mulyana, Deddy. (2006). Metodologi Penelitian Kualitatif. Bandung: PT Remaja Rosdakarya.

Nazir, Mohammad. (2011). Metode Penelitian. Bogor: Ghalia Indonesia.

Novita, Pipit (2004). "Makna Doa-Doa Dan Pelengkapang Sajian Perayaan Tahun

Nurhakim, Moh. (2003). Islam, Tradisi \&amp; Reformasi: "Pragmatisme" Agama Dalam Pemikiran Hassan Hanafi. Jurnal UIN Alauddin.

Paramita, Sinta (2018). "Pergeseran Makna Budaya Ondel-Ondel Pada Masyarakat Betawi Modern". Jurnal Bhakti Masyarakat.

Richard West, Lynn H.Turner. (2008). Pengantar Teori Komunikasi: Analisis dan Aplikasi (Buku 2) (Edisi 3). (Putra, Penerjemah). Jakarta: Salemba Humanika. 
Samovar, Larry A, et al. (2010). Komunikasi Lintas Budaya. Jakarta: Salemba Humanika.

Sanjaya, Oktavia. (2016). "Fungsi Dan Makna Penyambutan Hari Raya Imlek pada Masyarakat Etnis Tionghoa Di Kota Bandar Lampung”. Jurnal Skripsi Fakultas Ilmu Sosial Dan Ilmu Politik Universitas Lampung.

Sobur, Alex. (2003). Semiotika Komunikasi. Bandung: PT. Remaja Rosdakarya.

Sugiyono. (2011). Metode Penelitian Pendidikan Pendekatan Kuantitatif, Kualitatif dan $R \& D$. Bandung: Alfabeta.

Sugiyono. (2014). Metode Penelitian Kuantitatif, Kualitatif, dan R\&D. Bandung: Penerbit Alfabeta.

Sugiyono. (2016). Memahami Penelitian Kualitatif. Bandung: Alfabeta.

Susanto, Eko Harry. (2018). Komunikasi Manusia : Teori dan Praktik Dalam Penyampaian Gagasan, Mitra Wacana Media Sumber Online.

Ulya, Yanti Azmah. (2013). "Makna Lampion Merah Dalam Kebudayaan Cina DI Jakarta”. Jurnal Karya Ilmiah Fakultas Ilmu Pengetahuan Budaya. 